\title{
The role of Politics and Economics in the International Financial Reporting Standards (IFRS) Adoption
}

\author{
ARACELI MORA \\ Universidad de Valencia, Facultad de Economía, Avda. Los Naranjos, s/n, 46022, Valencia, Spain. E- \\ mail: Araceli.Mora@uv.es
}

\begin{abstract}
IFRS adoption in EU since 2005 conveys benefits, but the evidence shows that they are unevenly distributed among different countries due to differences in institutions and incentives. The Contracting Theory offers a theoretical framework for the research on economic consequences and incentives of different stakeholders to lobby, but research on activity of politicians to interfer in accounting is scarce. The aim of this paper is to show the role of politicians and governments on accounting properties. With this purpose changes done in the EU endorsement process in the name of the "pubic interest" are analyzed. Research on how political interference has worked, especially in the financial industry is shown. We conclude that interested parties should compromise to get a balance between principle based standards and enforcement to improve the comparability process through IFRS.
\end{abstract}

Keywords: IFRS Adoption, Lobbying in Accounting, EU Endorsement Process, Political Interference in Accounting.

\section{La influencia de la política y la economía en la adopción de las Normas Internacionales de Información Financiera (NIIF)}

\begin{abstract}
RESUMEN
La adopción de las NIIF desde 2005 ha conllevado beneficios, pero la investigación también ha demostrado que su efecto no ha sido uniforme en los distintos países debido a las diferencias institucionales y en los incentivos. La teoría contractual ofrece un marco teórico para la investigación de las consecuencias económicas y de los incentivos de los grupos de interés para ejercer presión, pero la investigación sobre la actividad de los políticos para interferir en la contabilidad es escasa. El objetivo de este estudio es mostrar el papel de los gobiernos en la contabilidad. Para ello se muestran los cambios acontecidos en el proceso de adopción de las NIIF en la UE para incrementar la interferencia política en nombre del "interés público", destacando el caso del sector financiero. Se concluye que todas las partes involucradas deberían comprometerse a buscar el equilibrio entre normas basadas en principios y mecanismos de control para mejorar el proceso de comparabilidad con las NIIF.
\end{abstract}

Palabras clave: Adopción de las NIIF, lobbying en contabilidad, interferencias políticas en contabilidad.

JEL Classification: M48

Artículo recibido en febrero de 2018 y aceptado en abril de 2018

Artículo disponible en versión electrónica en la página www.revista-eea.net, ref. ə-36208

ISSN 1697-5731 (online) - ISSN 1133-3197 (print) 


\section{INTRODUCTION}

With effect from 2005, compliance with International Financial Reporting Standards (IFRS) from the International Accounting Standard Board (IASB) was made mandatory in the European Union (EU) for the consolidated accounts of companies with securities traded on a regulated market by Regulation 1606/2002. The Regulation also required EU Member States to take appropriate measures to ensure compliance (enforcement), which should lie on national institutions. The Regulation's objectives were: improved transparency and comparability, better functioning of the internal market, the efficient and costeffective functioning of the capital market, the protection of investors and maintenance of confidence in capital markets, and helping EU companies compete on an equal footing for capital within the EU and on world capital markets.

As pointed by ICAEW (2014) it is not possible to draw indisputable conclusions on the overall effects of mandatory IFRS adoption based on the available accounting empirical research, but it seems likely that there were overall benefits to transparency, comparability, the cost of capital, market liquidity, corporate investment efficiency and international capital flows associated with the mandatory adoption of IFRS in the EU. Nevertheless, the research also clearly shows that these benefits were unevenly distributed among different firms and different countries due to differences in institutions and incentives. In a global perspective, according to Wysocki (2010), countries with different sets of institutional endowments are likely to select different accounting standards, so any change in a standard cannot be considered in isolation from other elements of their institutional infrastructure. Zeff (2007) highlights that "comparability is a very difficult notion to understand even within a country, let alone globally. We have not really had much literature that helps us understand what is meant by comparability” (Zeff, 2007, page 290).

In his seminal work, Zeff (1978) referred to the "economic consequences" of accounting standards. He noted that, increasingly, stakeholders attempted to influence standard setters not only by providing technical arguments for or against certain rules, but also, by raising awareness of alleged detrimental economic consequences of proposed changes. These "unintended" consequences necessarily put some interest groups at an advantage over others. The impact of an accounting standard among countries will be clearly different as the contracts (individual or collective, as regulations) based on accounting numbers differ substantially among the different jurisdictions (for example: taxes, distribution, compensations, capital regulatory requirements in banks, etc...).

The Contracting Theory offers a theoretical framework for the research on economic consequences and basically on incentives of different stakeholders to prefer an accounting treatment. Most of the research in this area, including 
research on lobbying, has mainly focused on incentives for the entities (preparers). However, research on the use of accounting as well as the lobbying activity by governments and politicians is scarce. The fact is that redistributive effects that accounting numbers may entail provide politicians with incentives to use accounting as a political tool (Alesina and Tabellini, 2004; Wagenhofer, 2014). National politicians may interfere in accounting rules directly by issuing national accounting standards when they are under their scope, although in an international context, having a global private standard setter, the IASB, makes the politics of the process much more complex.

As stated by Zeff (2005) ${ }^{1}$ accounting standards setting chronicles the rising importance of financial accounting standards in different sectors of economy, which has led to increasing special-interest lobbying for accounting standards with characteristics compatible with the desired outcomes. Financial accounting standards affect economy in many ways, both in the aggregate and in the distribution of income, wealth, and risk.

The loss of sovereignty for national governments had in relation with accounting standard setting process after adoption of IFRS has increased their lobbying activity, sometimes not in a very transparent way. Governments and politicians may exercise interference in accounting through several additional mechanisms, such as controlling the national enforcers, as well as, in some specific circumstances, interfering in the accounting practices by having a stake in firms.

The aim of this paper is to show, from a research perspective, the role of politicians and governments on accounting properties since the IFRS were adopted in Europe. We use first a descriptive methodology to determine and describe the way politicians, and other stakeholders, have been involved in the standards setting process in Europe, as well as the evolution of this involvement since de adoption of IFRS. Then, our research method to get evidence and analyse the motivations and potential implications of political interferences in accounting, is primarily based on a review of relevant literature both, theoretical and empirical. We also analyse descriptive and case studies to illustrate how this interference works in particular cases.

In particular, we analyze changes in the endorsement process in the last years to increase the level of political interference and the lobbying activity in the name of the "pubic interest". We will illustrate how it has worked specially in a very sensitive industry from the economic, but also political perspective: the financial industry. As IFRS adoption has been part of a broader package of institutional background, its success should be judged in part by its effects on surrounding institutions (politicians, national governments, enforcers, other

\footnotetext{
${ }^{1}$ http://archives.cpajournal.com/2005/205/infocus/p18.htm
} 
regulators...). Differing institutions and incentives inevitably mean that its effects vary not just from firm to firm, but also from country to country. We conclude that if the EU wishes to achieve further progress in financial reporting it may be necessary to take into account the incentives for those involved in the financial reporting process, including those of specific countries institutions and enforcers.

The structure of the paper is the following: section two refers to the IASB due process and the EU endorsement mechanism, basically to the changes adopted in the last years with the aim to increase politicians' intervention. Section three shows previous literature on theories and evidence of economic consequences driving lobbying activities, focusing on national governments. In section four, research evidence on political interferences in IFRS adoption is shown, mainly on the financial industry. Finally, in section five, some reflections on the future of comparability though IFRS.

\section{THE POLITICS OF THE IASB DUE PROCESS AND THE ENDORSEMENT MECHANISM IN EUROPE}

The international leadership of the IASB as a worldwide standard setter hinges critically on legitimacy (Prada, 2013). To obtain political legitimacy, the IASB has established the "due process". According to legitimacy theory, the legitimacy of a privately organized accounting authority is linked to its ability to provide an "optimal" information or pay out determination system that institutions accept as a result of decisions from bounded rationally acting individuals. It follows that legitimacy of a standard setting process is therefore not subject to the individual's ability to provide an "optimal" system of rules, but to the ability to develop rules acceptable to its constituency. In theory "superior rules" must be understood as the result of a hypothetical negotiation of all affected individuals, meaning that all of them will benefit from the rules under consideration.

In general, accounting standard setting process is considered a political lobbying process through which participants have several means to influence outcomes (Sutton, 1984). In other words, standard setting becomes a political process when involved parties lobby both to safeguard their interests and to persuade the standard setter to approve the rules to their advantage. Consequently, the IASB has the role of resolving conflicts among interested groups by trying to find a solution acceptable to various constituencies.

The IASB' due process, which is set out in its due process handbook (IASCF, 2011), requires proposals for public comment at each stage of the standard setting process (discussion papers, exposure drafts) before issuing a standard (or amendment or interpretation). This due process allows a certain level of transparency in the lobbying, but it is not the only way constituents might pressure the standard setter, mainly if they are powerful. 
When the European Commission (EC) issued Regulation 1606/2002 introduced requirements for the consolidated accounts of companies in the EU whose securities are traded on regulated markets in the EU to be prepared in accordance with IFRS as adopted by the EU ${ }^{2}$. The European Commission (EC) decided to have an endorsement mechanism by which individual standards were given the force of law within the EU. A very significant distinction between this and the previous harmonisation strategy through Directives is that the latter have to be absorbed into national law, while the use of IFRS would be mandated at EU level through a Regulation which overrides national law.

In its origin, the EU endorsement system would consist on the actions of two bodies: First, the European Financial Reporting Advisory Group (EFRAG), composed by a body of technical experts (TEG) which would engage with the IASB upstream of the issue of standards, and would advise the Commission on whether a standard should subsequently be endorsed for use in Europe ("endorsement advice"). The Commission would then ask to a second body, the Accounting Regulatory Committee (ARC), which would consist of representatives of member states, if it will support endorsement. Thereafter the endorsement was sent to the European parliament for information purposes, and endorsement was formally given by the Council of Ministers. However, once the IFRS were already in place in 2005 there were some significant changes. Through an agreement with the EC in 2006 the EFRAG was identified as the EU's official advisor on IFRS and the larger EU member states also started to develop funding mechanisms to channel more resources to EFRAG. Separately, the European Parliament was given at the same time the right to consider proposed endorsements during a three-month period after approval by the ARC.

When the final standard (or amendment or interpretation) is issued, the endorsement process starts. EFRAG has to carry out an assessment of the standard (amendment or interpretation) against the technical criteria for endorsement set out in Regulation (EC) No 1606/2002. It has also to assess the costs and benefits that would arise from its implementation in the European Union (the EU) and European Economic Area in order to assist the European Commission in its assessment of whether the standard is conducive to the "European public good". At the same time the EFRAG became one of the most significant commentators on IASB Exposure Drafts. EFRAG also has its own "due process" on both, comment letters and endorsement advice (as well as any other document).

\footnotetext{
${ }^{2}$ The requirements applied to most EU publicly traded companies with effect from accounting periods ending on or after 31 December 2005. They applied with effect from accounting periods ending on or after 31 December 2007 to EU publicly traded companies that had only debt securities publicly traded or that had been complying with US GAAP in preparing their consolidated accounts, where Member States opted to allow such a delay.
} 
In 2006 a new body was established to monitor EFRAG, called the Standards Advice Review Group (SARG), which is intended "to satisfy potential critics that EFRAG's judgements are balanced and objective” and, as pointed by Zeff (2007) "whatever that means, SARG could also become the object of political forays". (Zeff, 2007, page 299)

As pointed by Van Mourik and Walton (2018) one of the fundamentals of the EFRAG when it was created was that it should be a private sector body, funded by interested organisations ${ }^{3}$. The "founding fathers" formed a supervisory board (EFRAG-SB) which together provided annual funding. The technical work was carried out by the Technical Expert Group (EFRAG-TEG), volunteers selected among candidates ${ }^{4}$ from different parts of the financial reporting world of preparers, auditors, users and academics. The national standard-setters were not involved in the funding of EFRAG at the very beginning, nor were they involved directly in the TEG. But once the IFRS were in place, the largest National Standard Setters (NSS) from UK, France and Germany (Italy was incorporated in 2010) became non-voting TEG members.

During those early years the endorsement process was called into question basically by the EC and some NSS ${ }^{5}$, while TEG in providing advice to the Commission had run into significant problems with the advice and eventual endorsement of some standards (for example: IAS 39 on financial instruments). This underlined the fragility worldwide of a system that depended on nation states giving up rule-making sovereignty to a private sector standard-setter (Van Mourik and Walton, 2018). In 2008 the standard setting system worldwide was obliged to address the financial reporting consequences of the financial crisis. At that time there was a reform of the supervisory board of the EFRAG so that it would no longer represent the funding organisations but be more widely representative. This was a condition imposed by the Commission when it decided at that time to start contributing to EFRAG funds itself (as well as to the IASB). In 2009 the IFRS Foundation created its Monitoring Board, on which the European Commission had a seat and therefore a new way of influencing the IASB. In 2010 the EC decided that the chair of the SB (an auditor) had to be replaced by an ex-politician, Pedro Solbes, the Spanish former minister and European Commissioner for Economic and Monetary Affairs.

There was a debate at that time about the advantages and disadvantages of

\footnotetext{
${ }^{3}$ The Commission turned to FEE, which put together a number of European organisations to fund and support EFRAG. The Union of Industrial and Employers' Confederations, the European employers' organisation (UNICE, now Business Europe), also played a prominent role.

${ }^{4}$ Aside from the chairman, who is now full time, the members of TEG are part-time and do not receive any remuneration or reimbursement of expenses.

${ }^{5}$ See Van Mourik and Walton (2018).
} 
the whole European accounting process and the political inferences on it (see for example Alexander and Eberhartinger, 2010; Canfferman and Zeff, 2015 ${ }^{6}$ ). The EFRAG-TEG remained at the heart of EFRAG's technical activity and its was its responsibility to issue comments letters and endorsement advice, while the EFRAG-SB just monitored from the distance the diligence of the process. The TEG remained without significant changes till 2015. It had 12 voting members and the aforementioned 4 non-voting members from the largest NSS. The chair of TEG was the president of the EFRAG.

However, there was a significant change in the governance of EFRAG in 2014. This fundamental change in the endorsement structure started in 2013 when Commissioner Michel Barnier, in response to a request from the Council of Ministers, asked Philippe Maystadt, a Belgian former finance minister, to prepare a report analysing the endorsement system and recommending improvements. It was argued that the aim was to reinforce the European voice in IFRS standard-setting. The "Maystadt report" (Maystadt, 2013) argued that there were concerns in the wake of the financial crisis that Europe had insufficient influence over IFRS. And Maystadt was making the judgment that all the efforts that had been made by the European Commission to achieve a single voice for Europe through the endorsement process had not been sufficient. He considered several ways of changing the situations and finally recommended the change in the EFRAG governance structure and due process. This change was effective in October 2015 and it had two main significant consequences. EFRAG-TEC stayed similar in composition and in charge of the technical issues, but the four standards setters became voting members. Since then, the EFRAG-Supervisory Board became the executive power and changed its composition. The EFRAG Supervisory Board monitors the work of the Technical Expert Group and ascertains that the individual members work in the "European public interest". All documents issued by TEG were addressed to the EFRAG-SB who is the responsible of getting "consensus" (if possible) on their content, taking into consideration other "non-technical" issues in its final decision. It makes its decisions to the extent possible on the basis of consensus with the objective of Europe speaking with one voice. The EFRAG-SB includes 8 representatives of European Stakeholder Organizations and 8 National Standard Setters ${ }^{7}$ and is led by a President nominated by the European Commission (after having heard the European Parliament and the Council of Ministers). The European Commission, the European Supervisory Authorities

\footnotetext{
${ }^{6}$ This book gives a deep and interesting overview on the IASB since its origin in 2001 till 2011, including its relation with Europe, and in particular some aspects related with political interferences.

${ }^{7}$ In order to be part of the SB the NSS must provide finding. In 2015 national funding mechanisms provide 25\% of the money to run EFRAG. The Spanish standard setter, ICAC has recently been included in the EFRAG-SB.
} 
and the European Central Bank (ECB) participate in the EFRAG Board in an observer capacity.

In summary, the final decision of EFRAG has been transferred from the individual decisions of the technical group to institutional decisions of representatives of stakeholders and national and European institutions. The lobbyist process of the national standards setters (with different level of influence of their national governments) and the EC becomes less visible and more effective. The potential unintended consequences of the standards, whatever they might be, become part of the goals of the EFRAG analysis, beyond the technical analysis provided by TEG.

If all these efforts are seriously addressed at the European level to enhance the European Union's influence on international accounting standards, as pointed by Van Mourik and Walton (2018) it does not sound strange that the IFRS Foundation raised some concerns about the Maystadt Report, including concerns about the risks associated with Europe introducing an endorsement mechanism that has the potential to introduce changes to European accounting standards that deviate from international norms.

The above described concept of endorsement is not unique to Europe, but is used here to understand how politics and business environment can influence the "adoption" of IFRS in countries and legal jurisdictions around the world.

\section{THE ECONOMIC CONSEQUENCES OF IFRS AND THE PUBLIC INTEREST}

In spite of the scarce evidence that the pure "public interest theory" fits with the role of accounting standard-setters, the notion of 'public interest' pervades the legislation and regulations relating to the standard setting process in the EU and in other jurisdictions, and yet it is a term that has proven difficult to define (Abela and Mora, 2012). The International Federation of Accountants issued a paper (IFAC, 2012) concluding that it was not possible to define "public interest" but that, at best, professional bodies and standard-setters would know that they are acting in the interest of the public at large when they observe a process that is open and transparent, whilst being sensitive to the local culture and practices.

Although we argue that unintended consequences are not really a cost of the standard, as the contracts (individual or collective) could be adjusted, knowing about those potential consequences is very important to predict the final impact on the behavior of stakeholders, and then, the adequate application of the change to get to the final intended objective.

For that reason, it seems that the "intended "effect of a change in the standards can affect differently depending on the jurisdiction and, without any doubt, the 
"public interest" considering a nation in isolation could differ significantly from country to country. In addition, all stakeholders tend to consider their own wealth as a "public interest" matter. In fact, as Kvaal and Nobes (2011) show the national patterns in the use of IFRS continue after the 2005 adoption. Accordingly, the "European interest" or "European public good" could have a vague meaning.

Being that the IASB is an international standard setting body, arguments from stakeholders based on country-specific economic consequences are less likely to lead to successful lobbying. Durocher et al. (2007) identify the Economic Theory of Democracy (ETD) as a key theoretical framework for the analysis of the lobbying process. ETD links the decision to participate in the standard setting process to the decision to vote in a political system. According to ETD (Sutton, 1984; Tandy and Wilburn, 1992; McLeay et al., 2000) the propensity for lobbying is hypothesized to be increasing in both (i) the magnitude of the perceived wealth effect, and (ii) the expectation of influencing the final decision. An individual will participate if the perceived benefits of doing so, including the probability of influencing the outcome, exceed the costs. Participation will be concentrated among those who bear economic consequences most heavily. Given that participating is costly, only those expecting benefits from participating will do so if they can afford the cost. Positive accounting theory thereby provides a link between the economic consequences of a proposal and the individual wealth of those participating in the due process. However, it is remarkable that national standard setters might play a decisive role, they can be much stronger influenced by country specific circumstances and are easier to be lobbied. This lobby activity on national standards setters has been evidenced in Zeff (2006) for the case of USA, even with a private standard setter as it is FASB. He documents how while members of the US Congress cannot prevent the FASB from issuing a standard, they can introduce legislation ordering the Stock Exchange Commission (SEC), a governmental agency, not to require companies to follow the standard. If the national standards setter is a governmental agency this situation could be even more obvious, and if they have power in the standard setting process the effect could be very remarkable.

For example, that would be the case of the pressure that two French Presidents made to the IASB. Firstly, in 2003 with Jacques Chirac, when banks persuaded him to send a letter to the EC in order to ask the IASB to modify IAS 32 and 39. Secondly, after the financial crisis, French banks persuaded Nicolas Sarkozy to ask René Ricol, a former President of the International Federation of Accountants (IFAC) to give an opinion about how IFRS place European banks in an unfavourable position in relation with their US counterparts. As described in Camfferman and Zeff (2015) also the episode of allowing reclassification of financial instruments held at fair value to other categories instigated by the EC was a clear interference on politicians with their own goals in mind. 
The fact that some national accounting standard setters get power in the endorsement process through EFRAG the most likely the national ("public") interest become an issue, even if it is called "European Public Interest".

However, as explained and illustrate in the next section, there are other ways of politicians and governments interfering in accounting and using accounting as a tool to get their aims.

\section{THE POLITICAL/GOVERMENTAL INTERFERENCES ON IFRS ADOPTION}

Governments (and politicians in general) may lobby in the due process to produce accounting standards as any other stakeholder as previously shown, but they can also use other less transparent procedures to affect accounting numbers. The loss of sovereignty for jurisdictions decision to adopt IFRS in the European Union implied an increase of the national governments lobby on IASB as already mentioned basically under the "public interest" notion. However, prior work supports the view that politicians often use their own preferences in deciding whether to maintain or reform the law, try to please voters to win elections, or simply value short-run economic effects while discounting longer-run consequences (Walsh, 2005). The accounting theories and hypotheses state that self-interest might have played a significant role in Governmental decisions (Giner and Mora, 2018b).

The fact that enforcement of IFRS is done at national level has been commonly seen as a key aspect to prevent comparability. It is not easy to get empirical evidence of the national enforcers' attitudes. However, in some cases it is so visible that it can serve to illustrate our argument. One example is the attitudes towards bank accounting.

\subsection{Accounting for loan impairments}

As pointed by Giner and Mora (2018a) banks are regulated institutions mainly because they are vital for financial stability. Indeed, the shock waves caused by a banking crisis may clearly affect the entire economy. Due to both, the nature of the assets (basically loans) and the financial structure of banks, information asymmetries which convey specific moral hazard with depositors deserve special attention. Due to the illiquid market that characterizes loans, managers can exercise high discretion in valuation of loans. If banks do not take into account the interests of depositors or those of society as a whole, then market discipline becomes necessary. But, as Nier and Baumann (2006) sustain, the effectiveness of market discipline is contingent upon several aspects, and reporting risk information about loans is a key issue for this effectiveness. However, providing information about the quality and creditworthiness of loans through accounting seems to be a special matter for controversy between 
prudential regulators and accounting standard setters, and the role of accounting information and, in particular, loan loss recognition become an issue within the discussion. At the same time, prudential regulators exercise a monitoring role in the economy, which makes them both powerful and vulnerable to political interference.

The interference of prudential rules with loan loss accounting has been always a matter of concern (Gray and Clarke, 2004). As Wall and Koch (2000) argue, among the accounting profession there is high consensus on the inappropriateness of using the prudential perspective for accounting purposes, as recording "expected losses" facilitates earnings management reducing the quality of the information.

In Europe, before the introduction of IFRS in 2005, recording expected loan losses in accounting earnings was common practice. Moreover, in some countries prudential rules were followed to estimate impairments to be charged in the profit and loss account. Furthermore, prudential models have sometimes been used for clear accounting purposes. Thus, the allowance has been employed as a countercyclical mechanism by requiring banks to build up a fund during good times (large impairments even if there are no signs of any problems), which might be depleted in downturns (low impairments when problems occur); this system smooths reported accounting profits over time. The 'dynamic provisioning' introduced by the Bank of Spain in 2000 is a good example of this practice. Although some authors are supportive of using such dynamic provisioning as an accounting model for impairment (Poveda, 2000, Bouvatier and Lepetit, 2008; Pérez et al., 2008), most auditors, practitioners, and accounting scholars are strongly opposed (FEE-EFRAG, 2009; Barth and Landsman, 2010; Laux, 2012; Acharya and Ryan, 2016).

International Accounting Standard 39: Financial Instruments. Classification and Measurement (IAS 39) adopted in 2005 states that loan impairment has to focus on losses resulting from events that have already happened. It considers losses derived from past and present events, these are the so-called incurred losses and, contrary to the prudential models, explicitly excludes the expected effect of future events (based on forward-looking information), so expected losses.

However, in the banking industry, there is indirect evidence of potential interference on accounting practices, specifically on the recognition of impairment losses through the action of prudential supervisors (Gebhardt and Novorty-Farkas, 2011). Bank regulators and supervisors have a clear preference for larger impairments, and can influence accounting practice (Levitt, 1998; Gray and Clarke, 2004). Powerful prudential supervisors, that are not independent, are an effective mechanism for national governments to influence accounting practice (García Osma, Mora and Porcuna, 2017). As Quintyn et al. (2007) point out, this 
political interference might lead in some cases to the prolongation of the life of insolvent entities, leading therefore to unfair competition and higher cost for taxpayers at a later stage.

As a consequence of the recent financial crisis, the debate regarding the interpretation of expected losses arose again. ${ }^{8}$ There was a concern mostly among prudential regulators that the stronger reliability of an incurred loss model was achieved at the expense of relevance by delaying the recognition of bad news, and even, in some cases, overstating the values of the lowest quality loans. It is not clear, however, if the problem lay with the loan loss accounting model or in the way it was implemented. Hence it could be the case that, as pointed by the IASB Chairman, the 'too-little-too-late' problem could have been avoided, at least partly, if the incurred loss model had been applied much more vigorously (Hoogervorst, 2012).

However, while during the boom period at the end of the century the dispute ended with a stricter application of the accounting standards, the incurred loss model, it seems that on this occasion the standards have been changed, and International Financial Reporting Standard 9: Financial Instruments (IFRS 9) will be in place since 2018. This standard has an impairment model which partially includes some forward-looking information ${ }^{9}$ and it is easier to be influenced by prudential institutions (Novorty-Farkas, 2016).

Also the literature evidences that politicians affect directly the accounting practices in politically connected firms. Political connections have been documented to incentivize reporting lower earnings quality and transparency (Chaney, Faccio, and Parsley, 2011; Leuz and Oberholzer-Gee, 2006). Furthermore, national elections have been shown to promote manipulating behavior by politically connected firms (Ramanna and Roychowdhury, 2010) consistent with Jones (1991)'s extension of the Watts and Zimmerman (1978; 1986)'s political costs hypothesis following a dual objective of minimizing the political costs associated with increased political scrutiny for themselves and for the candidates they support. As pointed by Giner and Mora (2018b) banks, in a more remarkable way when they are politically connected, are a good example of this interference.

In some extreme cases, as it happened in Spain, the interference of Governments is the adoption of IFRS is rather obvious, as we illustrate below.

\footnotetext{
${ }^{8}$ A good illustration of this debate can be seen in Dugan (2009), a prudential supervisor who claims for larger provisions charged in the profit and loss account during good times. He complains about managers and auditors for not doing so due to the accounting standards in place at that time (the incurred loss model). Available at: https://www.occ.gov/news-issuances/speeches/2009/pubspeech-2009-16.pdf (last accessed 06.03.17).

${ }^{9}$ See details in Hashim et al. (2016).
} 


\subsection{The Spanish case}

It is a matter of fact that banks in Spain do not comply with IFRS (more concretely IAS 39) and this has been recognized at the international level (Mora, 2014). As previously mentioned the accounting academics and regulators pointing the inappropriateness of the "Spanish dynamic provision" for accounting purposes are clarifying this model is not in accordance for IAS 39, but additionally the non-compliance of IFRS of Spanish banks has been explicitly recognized in some forums (Giner and Mora 2018b).

The financial entities in Spain follow Bank of Spain (BdE) rules, called Circulares. The Bank of Spain was the first to "adapt" accounting rules for financial entities to IFRS principles. Circular 4/2004 of the Bank of Spain was approved in order to modify the accounting system for Spanish credit institutions (with several modifications in later years).

There are two remarkable aspects to this rule. The first is that in the preamble it stated that "The Circular is applicable in the preparation of the public financial statements and confidential returns for both individual and consolidated accounts of credit institutions and branded in Spain of foreign credit institutions". This is obviously incompatible with the direct application of IFRS in consolidated accounts of listed companies. The second one is that, according to the Circular "they try to align the accounting objectives and the supervisory and macroprudential aims to increase stability". This last aim is the main reason why the "impairment model" for financial instruments according to this rule, the so named "dynamic provisioning" is not compatible with IAS 39 criteria for impairment. Both aspects are remarkable because Spanish listed banks have not followed IFRS but instead have used the Circular when preparing their consolidated accounts ${ }^{10}$.

The political interference of the Spanish Government in the accounting standards reached a climax in 2012. In the second half of 2011 the debt crisis had not been solved and some financial entities (mainly saving banks) started to worry about the high increase of non-performing loan for the next years. National elections led to a change from the socialist party (PSOE) to the conservative party (PP) in December 2011. The newly elected Government faced a dilemma between calling for a bailout for the whole country or asking for a specific type of financial aid which would allow the recapitalization of banks. As stated and illustrated in detail in Giner and Mora (2018b), this second option was chosen ${ }^{11}$.

\footnotetext{
${ }^{10}$ For more details see Mora (2017).

${ }^{11}$ This paper uses a highly politically connected entity, Bankia, to illustrate an extreme case of impairment manipulation, not just using the rules but also by earnings management in the entity in the period 2012-2015 is consistent a theoretical background based on legal theories which go beyond the traditional cost hypothesis.
} 
Notwithstanding this, it should be kept in mind that according to the 2009-2011 accounting earnings, as well as the stress tests performed by the European Banking Authority (EBA) ${ }^{12}$ referred to December 2010, Spanish banks were "safe" at that time (Climent and Pavía, 2015). In fact, as pointed by Sevilla et al. (2017) the information about the financial sector reported by the Bank of Spain at those years (2009-2011) showed a financial situation quite stable compared with the rest of Europe, including the situation of the saving banks that would collapse in the following years.

As Giner and Mora (2018b) highlight, with the aim to restructure the "weak" financial sector, the newly elected Government bypassed the authority (at least for individual accounts) of the Bank of Spain and issued in February and May two Royal Decree Laws (RDL), which modified the accounting impairment rules to estimate the specific allowance. ${ }^{13}$ The change was mainly oriented to the re-measurement of the accumulated impairment (allowance) of financial assets (basically loans) linked to the construction and real estate sectors existing on $31^{\text {st }}$ December 2011, and affected not only individual but also consolidated statements. These RDLs required to compute a larger specific allowance by increasing the percentages to be applied to all these investments, even if they had not any evidence of being impaired at all, this is performing loans, which contradicts IAS 39. Moreover, the RDLs stated that the impact of this policy change should be considered a "change in estimation", and be recognized in the 2012 net income or partly delayed to 2013 if there were M\&A ${ }^{14}$. This treatment is contrary to IAS 8 (IASC 1978a) (Mora, 2012; Giner, 2014). Additionally, if those impairments were not related with incurred losses, it allows earnings management in later periods, and more concretely the so called "big bath accounting” (Giner, 2014; Climent and Pavía, 2015; Giner and Mora, 2018b), consisting in a one-time overstatement of charges against income to undervalue net assets, which reduces future expenses and increases future income accordingly. This strategy has been identified in non-routine executive changes, as the new executives' image improves by showing a better performance when they are in charge.

The fact is that countercyclical mechanism of the dynamic provision applied to accounting worked as expected during the first years of the financial crisis.

12 The results of the stress test are available at: http://www.eba.europa.eu/risk-analysis-anddata/eu-wide-stress-testing/2011/results (accessed 20 December 2017).

${ }^{13}$ The RDLs were known as the "Guindos Decrees”. De Guindos was the new elected Ministry of Finance. After the two RDLs, Bank of Spain issued two new regulations (Circulares) in February and September respectively, which modified Circular 4 /2004 to adapt it to the 2012 RDLs.

${ }^{14}$ This is indeed an incentive to promote those transactions, and once again evidences the use of accounting as a political tool. 
Thus, although in 2008 the delinquency rate in the Spanish financial industry grew to converge with European figures, and by 2010 the Spanish financial system was in serious trouble (Maudos, 2011), the earnings figures disclosed by the Spanish financial industry covered up their financial difficulties. Consequently, in June 2011, judging by the stability of accounting earnings, the health of the Spanish banking system was better than the average European bank (Carbó and Maudos, 2011) which means that this system was hiding problems and probably delaying the solutions. The trend of impairments recognized by Spanish financial entities in their accounting earnings is inconsistent with the evolution of bad debts which evidences the non-compliance with the standards in place and seems to be linked with Governmental goals (Giner and Mora, 2018b).

Figure 1

Delinquency (bad debts) trend in commercial banks index 100 $=2006$

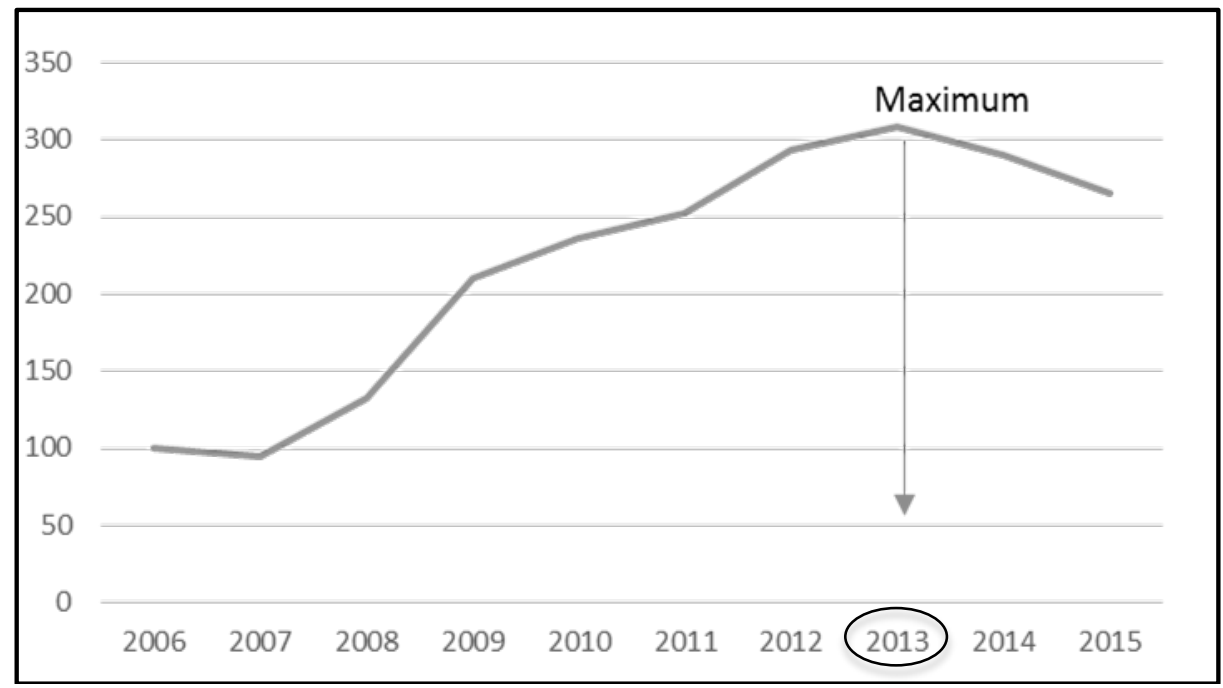

Source: Author, based on information from Asociación Española de Banca (AEB) (www.aeb.es) and the Financial Stability reports issued by Banco de España. (www.bde.es)

Some figures may help to appreciate that the trend of impairments recognized by Spanish financial entities in their accounting earnings in the period 2006-2015 is inconsistent with the right application of IAS 39. If impairments are "incurred losses" (with objective evidence of deterioration) its trend should be related with the evolution of bad debts. This evolution of bad debts (delinquency) is also related with the trend of some macroeconomic variables as for example unemployment. In fact, Figures 1 and 2 shows how bad debts (delinquency) trend in Spain was similar to unemployment trend on that period. Both started to increase in 2008 and reach its peak in 2013. However Figure 3 shows how impairments in the Spanish commercial banks follow a different pattern. While 
Figure 1 shows the bad debts growing continuously till 2013, when the delinquency rate was at its maximum ${ }^{15}$, Figure 3 shows that impairments behave differently. This is specially the case since the beginning of the financial crisis in 2008; the smoothing of impairments due to the Spanish dynamic provision is clearly visible in 2009-2011, while the peak in 2012 captures the huge impairments imposed by the Government through the two RDLs. ${ }^{16}$

Figure 2

Unemployment rate trend, index 100 $=2006$

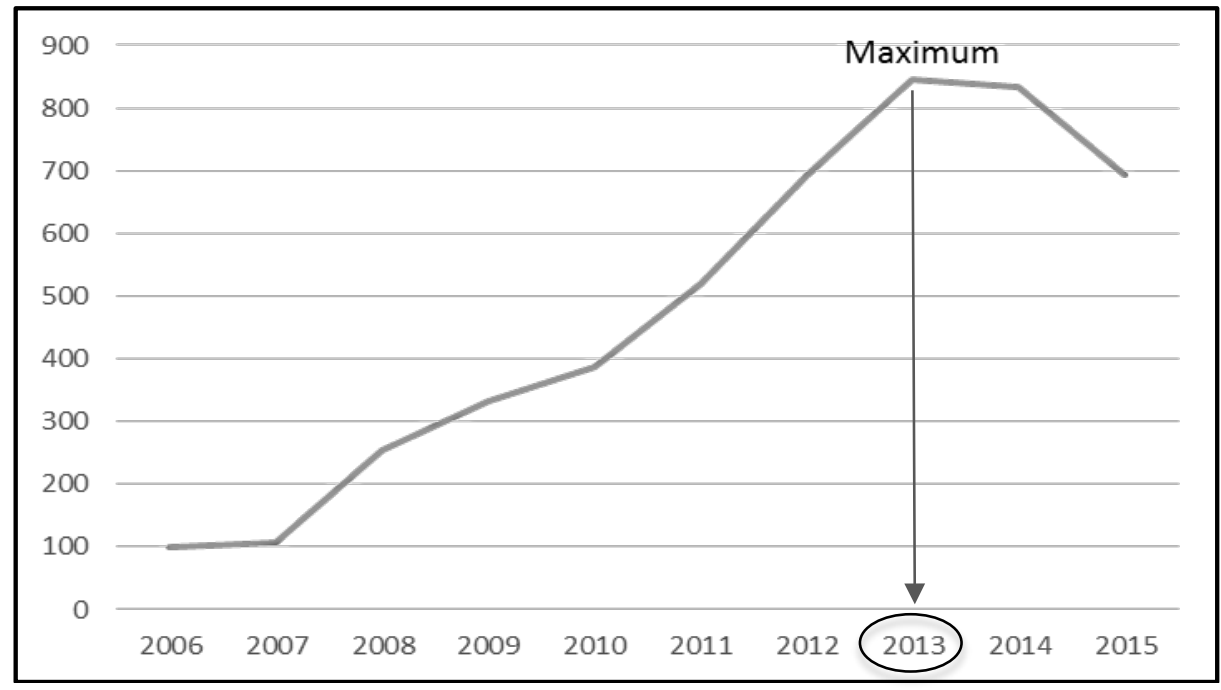

Source: Author, based on information from Instituto Nacional de Estadística (INE) (www.ine.es)

In summary, these figures show as the trend of impairments in accounting earnings in the Spanish financial sector has been driven by political actions and it is completely unrelated with the economics of those entities, as it should be in IFRS would have been properly applied.

${ }^{15}$ According to BdE, the delinquency rate was the maximum in the last fifty years (BdE, 2013) https://www.bde.es/f/webbde/Secciones/Publicaciones/InformesBoletinesRevistas/InformesEst abilidadFinancera/13/IEF-Noviembre2013.pdf (accessed 20 December 2017).

${ }^{16}$ The aggregated information in the figures refers to commercial banks and does not include the Cajas. Nevertheless, most of them disappeared between 2010 and 2012 due to the mergers, and after that date due to the bankruptcy caused by the application of the RDLs. 
Figure 3

Impairment trend in net income commercial banks index 100=2006

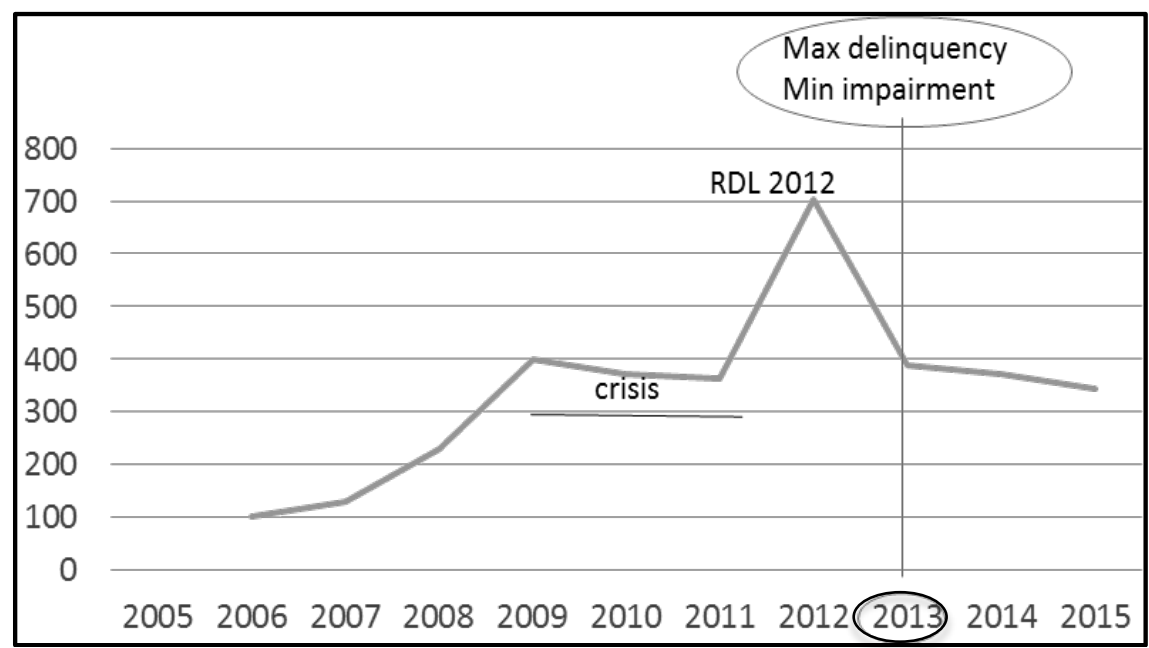

Source: Author, based on information from Asociación Española de Banca (AEB) (www.aeb.es)

\section{FINAL REFLEXIONS AND IMPLICATIONS}

This study shows how governmental/political interference has increased in the last years in the adoption of a common set of standards, IFRS, in all possible ways, by increasing the participation in the process, by lobbying IASB, by interfering in accounting practices and even by noncompliance with the rules.

It looks like we have a real problem to increase comparability with the aim of improving the efficient allocation of resources and reducing uncertainty in a global market. Under these circumstances some argue for addressing the efforts to the enforcement process. It seems the regulatory risks are not accurately considered when deciding non-compliance (Adams, 1994). In particular, the lack of regulatory sanctions, or litigation risks derived from breaking the accounting rules in specific cases might obscure the reputational risks, despite investors might have serious doubts about the credibility of the system as a whole.

However, there is also evidence that the more rigorous the enforcement mechanism, the more lobbying pressure that will be brought on the IASB, because companies in such countries will know that they have no 'escape valve', no way of side-stepping the adverse consequences. If the auditor is strict and the regulator is strict, political lobbying of the standard setter, the IASB, may become more intense (Zeff, 2007). According to this author, it seems that there are strengthened national regulators that appear to be taking more insistent enforcement positions, but in those countries, national standard setters seem to be 
more determined politicking on sensitive proposed standards: more pressure on the standard setter, more space in the standards allotted to exemptions to accommodate this pressure, and more detailed norms. The new leasing standard IFRS 16 seems to be a perfect example of this situation.

In summary, there seem to be serious obstacles to comparability and to convergence at a high level of quality. We tend to agree with Zeff (2006) when he argues that some of the obstacles are deeply cultural, while others are more susceptible to modulation. An appropriate balance between principle-based standards with some discretion to accommodate the specific institutional characteristics of the different jurisdictions and a serious enforcement mechanism to control compliance in the application of the standards would guarantee the quality of the information. This might help to the appropriate functioning of the markets and to accounting serving to that purpose. But this requires enlightened leadership and commitment from the accountancy profession, audit firm partners, and company accountants, as well as from national standard setters and the European Commission, to overcome these obstacles. We would say that academic research has a significant role to get this balance.

\section{BIBLIOGRAPHY REFERENCES}

ABELA, M. and MORA, A. (2012). "Understanding the Consequences of Accounting Standards in Europe: The Role of EFRAG". Accounting in Europe, 9(2), pp. 147-170.

ADAMS, G. (1994). "What is Compliance?". Journal of Financial Regulation and Compliance, 2(4), pp. 278-285.

ACHARYA, V. V. and RYAN S.G. (2016). "Banks' Financial Reporting and Financial System Stability". Journal of Accounting Research, 54(2), pp. 277-340.

ALESINA, A., and TABELLINI, G. (2004). "Bureaucrats or politicians". NBER Working Paper No. 10241 Cambridge, Massachusetts: National Bureau of Economic Research.

ALEXANDER, D. and EBERHARTINGER, E. (2010). "The European Union endorsement process for international financial reporting standards: A telos-based analysis". Accounting in Europe, 7(1), pp. 37-62.

BARTH, M.E and LANDSMAN, W.E. (2010). "How did financial reporting contribute to the financial crisis?"European Accounting Review,19(3), pp. 399-423.

BOUVATIER, V. and LEPETIT, L. (2008). "Banks' procyclical behavior: Does provisioning matter?". Journal of International Financial Markets, Institutions and Money, 18(5), pp. 513-526.

CANFFERMAN, K. and ZEFF, S.A. (2015). Aiming for Global Accounting Standards. The International Accounting Standard Board ,2001-2011. Ed. Oxford University Press. Oxford.

CARBO, S. and MAUDOS, J. (2011). "Reflexiones en torno a la reestructuración del sector bancario español”. Cuadernos de Información Económica, 221, pp. 81-96. 
CHANEY, P.; FACCIO, M. and PARSLEY, D., (2011). "The quality of information in politically connected firms". Journal of Accounting and Economics, 51(1), pp 58-76.

CLIMET SERRANO, S. and PAVIA J.M. (2015). "Bankia: ¿Para qué sirven los estados contables y los órganos de control?". Estudios de Economía Aplicada, 33(1), pp. 259300.

DUROCHER, S., FORTIN, A. and CÔTE, L. (2007). "Users' participation in the accounting standard-setting process: a theory-building study". Accounting, Organizations and Society, 32(1-2), pp. 33-63.

FEDERATION of EUROPEAN ACCOUNTANTS-EUROPEAN FINANCAIL REPORTING ADVISORY GROUP (FEE-EFRAG). (2009). Impairment of Financial Assets The Expected Loss Model, December. http://www.efrag.org/Assets/Download?assetUrl= \%2Fsites\%2Fwebpublishing\%2FSiteAssets\%2FEFRAG_FEE_Paper-

The_Expected_Loss_Model_Final\%2520-\%2520web.pdf [last accessed March, 2017].

GARCÍA OSMA, B.; MORA, A. and PORCUNA, L. (2018). "Prudential Supervisors' Independence and Income Smoothing in European Banks". Working Paper, University of Valencia. https://core.ac.uk/download/pdf/84750847.pdf, pages 167-205, [last accessed, 2018].

GEBHARDT, G. and NOVOTNY-FARKAS, Z. (2011). "Mandatory IFRS adoption and accounting quality of European Banks". Journal of Business Finance and Accounting, 38(3-4), pp. 289-333.

GINER, B. (2014). "Institutions and conflicts of interests in the international accounting regulation: The Spanish financial industry case". Spanish Accounting Review, 17(2), pp. 143-152.

GINER, B. and MORA, A. (2018a) Bank Loan Loss Accounting and its Contracting Effects: The New Expected Loss Models. https://papers.ssrn.com/sol3/papers.cfm?abstract_ id=3155105 [last accessed April 2018].

GINER, B. and MORA, A. (2018b). Political interference in financial reporting in the financial industry: Evidence from Spain. https://papers.ssrn.com/sol3/papers.cfm? abstract_id=3138620 [last accessed March , 2018].

GRAY, L.P and CLARKE, F.L. (2004). "A methodology for calculating the allowance for loan losses in commercial banks". Abacus, 14(3), pp. 321-341.

HASHIM, N.; LI, W. and O'HANLON, J. (2016). "Expected-Loss-Based Accounting for Impairment of Financial Instruments: The FASB and IASB Proposals 2009-2016". Accounting in Europe, 13(2), pp. 229-267.

HOOGERVORST, H. (2012). What and what not to expect of the expected loss model', 3rd ECB Conference on Accounting, Frankfurt, 4 June. http://www.ifrs.org/Alerts/ Conference/Documents/ECB462012.pdf [last accessed December 2016].

IASCF (2011). Due Process Handbook in International Financial Reporting Standards 2011. London: IASCF.

ICAEW (2014). The effect of mandatory IFRS adoption in Europe: a review of empirical research.https://www.icaew.com/-/media/corporate/files/technical/financial-reporting/ information-for-better-markets/ifbm/effects-of-mandatory-ifrs-adoption-april-2015final.ashx?la=en, [last accessed March 2018].

IFAC (2012). A definition of the public interest. https://www.ifac.org/publicationsresources/definition-public-interest. [last acessed March 2018].

JONES, J. J. (1991). "Earnings management during import relief investigations". Journal of Accounting Research, 29(2), pp. 193-228. 
KVALL, E. and NOBES, C. (2012). "IFRS Policy Changes and the Continuation of National Patterns". European Accounting Review, 21(2), pp. 343-371.

LAUX, C. (2012). "Financial instruments, financial reporting, and financial stability". Accounting and Business Research, 42(3), pp. 239-260.

LEUZ, C. and OBERHOLZERR-GEE, F. (2006). "Political relationships, global financing, and corporate transparency: Evidence from Indonesia". Journal of Financial Economics 81, pp. 411-439.

LEVITT, A. (1998). The 'Numbers Game,' September 28. Speech delivered at New York University Center for Law and Business. https://www.sec.gov/news/speech/ speecharchive/1998/spch220.txt [last accessed March, 2017].

MAUDOS, J. (2011). El sector bancario español en el contexto internacional: el impacto de la crisis. Madrid: Funcas.

MAYSTADT P. (2013). Should IFRS standards be more European? European Commission. http://ec.europa.eu/internal_market/accounting/docs/governance/reform/ 131112_report_en.pdf [last accessed March, 2018].

McLEAY, S.; ORDELHEIDER, D. and YOUNG, S. (2000). "Constituent lobbying and its impact on the development of financial reporting regulations: evidence from Germany". Accounting, Organizations and Society, 25(1), pp. 79-98.

MORA, A. (2012). "Banco de España vs NIC 39". Consejeros: la revista del buen gobierno y la responsabilidad corporativa, 71, abril, pp. 12-17.

MORA, A. (2014). "Usos y Abusos de la Contabilidad: El caso del saneamiento del sector financiero". Consejeros: la revista del buen gobierno y la responsabilidad corporativa 91, febrero, pp. 55-60.

MORA, A. (2017). "The Role and the Current Status of IFRS in the Completion of National Accounting Rules - Evidence from Spain". Accounting in Europe, 14(1-2), pp. 199-206.

NIER, E. and BAUMANN U. (2006). "Market Discipline, Disclosure and Moral Hazard in Banking". Journal of Financial Intermediation, 15, PP. 332-61.

NOVOTNY-FARKAS, Z. (2016). "The Interaction of the IFRS 9 Expected Loss Approach with Supervisory Rules and Implications for Financial Stability". Acccounting in Europe, 16(2), pp. 97-227.

PÉREZ, D.; SALAS FUMAS V., and SAURINA J. (2008). "Earnings and Capital Management in Alternative Loan Loss Provision Regulatory Regimes". European Accounting Review ,17(3), pp. 423-445.

POVEDA, R. (2000). "La reforma del sistema de provisiones de insolvencia". Boletín económico del Banco de España, January, pp. 79-92.

PRADA, M. 2013. The bumpy path towards global accounting standards. Speech at the IFRS Foundation Trustees in Franckfurt. http://www.ifrs.org/Alerts/Conference/ Documents/2013/Michel-Prada-speech-Frankfurt-October-2013.pdf. [last accessed September, 2013].

QUINTYN M.; RAMIREZ, S, and. TAYLOR M.W. (2007). "The Fear of Freedom. Politicians and the Independence and Accountability of Financial Supervisors" . In D. Masciandaro and M. Quintyn, (eds.): Designing Financial Supervision Institutions: Independence, Accountability and Governance, (Cheltenham/Edward Elgar, United Kingdom/Northampton, Massachusetts).

RAMMANA, K. and ROYCHOWDHURY, S. (2010). "Elections and discretionary accruals: Evidence from 2004". Journal of Accounting Research, 48(2), pp. 445-475. 
SEVILLA JIMÉNEZ, M.; TORREGROSA MARTI, T. y NÚÑEZ ROMERO, M. (2017). "La información financiera y bancaria oficial y la última crisis económica (1999-2012). El caso del Banco de España". Estudios de Economía Aplicada, 35(3), pp. 583-610.

SUTTON, T. G. (1984). "Lobbying of accounting standard setting bodies in the UK and the USA: a Downsian analysis". Accounting, Organizations and Society, 9(1), pp. 81-95.

TANDY, P. R., and WILBURN, N. L. (1992). "Constituent participation in standard-setting: the FASB's Wrst 100 statements". Accounting Horizon (June), pp. 47-58.

VAN MOURIK, C. and WALTON P. (2018). "The European IFRS endorsement process. In search of a single voice". Accounting in Europe, 15(1), pp. 1-32.

WAGENHOFER A. (2014). "Global Convergence of Accounting Standards". In The Routledge companion to accounting, reporting and regulation, eds. C. Van Mourik and P.J. Walton, Abingdon, Oxon: Routledge/ Taylor \& Francis Group, pp. 246-264.

WALL, L. and $\mathrm{KOCH}, \mathrm{T}$. (2000). "Bank loan-loss accounting: A review of theoretical and empirical evidence". Economic Review, 2, pp. 1-19.

WALSH, C. (2005). Central Bank Independence. Prepared for the New Palgrave Dictionary (December).

WATTS, R. L. and ZIMMERMAN, J. L. (1978). "Towards a Positive Theory of the Determination of Accounting Standards". The Accounting Review, 53, pp. 112-34.

WATTS, R. L. and ZIMMERMAN, J. L. (1986). Positive accounting theory. Englewood Cliffs, NJ: Prentice-Hall International Editions.

WYSOCKY, P. (2010). "IFRS and National Institutions". Information for Better Markets Conference: Adopting IFRS: The Global Experience, ICAEW, London, December.

ZEFF S. (1978). The rise of "economic consequences". The Journal of Accountancy, December, pp. 56-63.

ZEFF, S. (2005). "The Evolution of U.S. GAAP: The Political Forces Behind Professional Standards". The CPA Journal, January and February.

ZEFF, S. A. (2006). Political lobbying on accounting standards-national and international experience. In: Nobes, C., Parker, R. (Eds.): Comparative International Accounting, ninth ed. FT Prentice Hall, Harlow, Essex, UK, pp. 189-218.

ZEFF, S. A. (2007). "Some obstacles to global financial reporting comparability and convergence at high level quality". The British Accounting Review 39, pp. 290-302. 
